\title{
Hail Caesar!
}

\section{BY FLETCHER PRATT \\ A Biographical Study of Julius Caesar}

'His accounts of the campaigns, both of the Gallic and of the Civil Wars, are clear, lively and vigorous. His estimate of Cæesar's generalship ... is interestingly conceived and ingeniously argued. Mr. Pratt's interesting experiment in the matter of maps and plans ... is most successful.' Manchester Guardian

Illustrated

15s. net

\section{Wine-Dark Seas}

By Captain E. L. WHARTON, R.N.

An account of a cruise in a small yacht among the Isles of Greece

' His unaffected enthusiasm for the Odyssey ... and his skill in suggesting the atmosphere of a place ... carry one along very happily.'-Classical Revieno

'I am glad that Capt. Wharton has written Wine-Dark Seas . . . it has "go" in it."-Sin Jomn Sourre (Daily Telegraph)

Illustrated by the Author

12s. 6d. net

\section{Williams \& Norgate}

\section{The Loeb Classical Library \\ HITTED BY} †T. E. PAGE, c.H., I.ITT.D. $\begin{aligned} & \text { E. CAPPS, PH.D, LL. D. } \\ & \text { FOUNDED BY JAMES LOEB }\end{aligned}$

Bach volume, Fonlscas 8vo, 400-700 pages. Clear type. Cloth, 10s. net. Leather, 12s. 6d, net. A series of Greek and Latin Texts, with English Translations on the opposite page. The series is to contain all that is best in Greek and Latin Literature, from the time of Homer to the end of the Western Empire.

\section{'We chall never be independent of our Loeb. -Times Lir. SUPP. \\ New Volumes, Spring and Summer, 1938}

\section{Latin}

331. Ammianus Marcellinus. Three volumes. Vol. III (Books 27-32). Translated by J. C. Rolfr. 304, 336. Celsus. DE medicina. Three volumes. Vols. II and III. Translated by Dr. W. G. Spencer. 332. Livy. Thirteen volumes. Vol, XII (Books 40.42). Translated by the late EvaN T, SAGB

328. Plautus. Five volumes. Vol. V: stichos, TRINUMMUS, troculantos, vidoLARIA, FRAGMENTs. Translated by PaÚ Nixon.

329. Remains of Old Latin. Four volumes. Vol. III : Locilios, LAwS OF ThE XII IABLBS. Translated by E. H. WARMINGTON.

330. Pliny. Natural history. Ten volumes. Vol. I (Books I and 2). Translated by H. RackanM. 333. 334. Varro. DE lingda latina. Two volumes. Translated by Roland G, Kent.

\section{Greek}

325. Avistotle. organon. Two volumes. Vol. I : catrgorizs, on INTzRpretation, translated by H. P. COOKE; PRIOR ANALYTICs, translated by H. TRRDENNICK.

308. Minor Attic Orators. Two volumes. Vol. I: ANTIPHON, ANDOcIDEs, Translated by $\mathbf{K}$. Matdment.

Machines or Mind? (an introduction to the Loeb Classical Library).

Free together with Descriptive Prospectus, E-c.

WILLIAM HBI NEMANN, LTD., Windmill Prese, Kingewood, Tadworth, Surrey HARVARD UNIVERSITY PRESS. Cembridse, Mass.. U.S.A. 